\title{
Bioavailability of selected phytochemicals in the extracts of fluted pumpkin (Telfairia occidentalis), tomato (Lycopersicum esculentum) and eggplant (Solanum melongena)
}

\author{
Madukwe, E. U., Nwabunze, A. M*., Onyibalu, C. L. \\ Department of Home Science, Nutrition and Dietetics, University of Nigeria, Nsukka. \\ *Corresponding author E-mail: adaobi.nwabunze@unn.edu.ng
}

\begin{abstract}
Background: Enough information about the actual amount of individual phytochemicals in vegetables and the amount absorbed and utilized is not known.

Objective: This study evaluated flavonoid, saponin and phenol content of aqueous extracts of tomato, fluted pumpkin and eggplant as well as the bioavailability of these phytochemicals in rat.

Methods: The phytochemical content of the vegetable extracts and the serum, faecal and urinary phytochemicals were determined using standard procedures.

Result: The flavonoid content of tomato, fluted pumpkin and eggplant extracts were $90.23 \pm 0.04 \mathrm{mg} / 100 \mathrm{ml}$, $76.13 \pm 0.02 \mathrm{mg} / 100 \mathrm{ml}$ and $14.34 \pm 0.02 \mathrm{mg} / 100 \mathrm{ml}$, respectively. The eggplant extracts had the highest saponin $(73.29 \pm 0.46 \mathrm{mg} / 100 \mathrm{ml})$ and phenol $(158.14 \pm 0.05 \mathrm{mg} / 100 \mathrm{ml})$ content. The rats fed tomato extracts had the highest intake $(24.08 \pm 0.00 \mathrm{mg})$ and tissue store $(21.88 \pm 0.04)$ of flavonoid relative to the other extracts. The serum saponins for rats fed eggplant $(0.25 \pm 0.05 \mathrm{mg})$ extract was comparable to those rats fed tomato $(0.22 \pm 0.04 \mathrm{mg})$ and fluted pumpkin $(0.26 \pm 0.05 \mathrm{mg})$ extracts regardless of high intake $(17.77 \pm 0.01 \mathrm{mg})$. However, they had the highest tissue saponin $(16.87 \pm 0.05 \mathrm{mg})$. The group of rats fed the fluted pumpkin extract had the highest serum phenol $(0.49 \pm 0.06 \mathrm{mg})$.

Conclusion: The vegetables can be considered good sources of phytochemical since their extracts were rich in the phytochemical studied.
\end{abstract}

Keywords: flavonoids, phenol, phytochemical, saponin, vegetable extract

\section{Introduction}

Most bioactive food constituents are derived from plants; those so derived are collectively called phytochemicals [1]. Greater realisation of the importance of phytochemicals in promotion of human health has prompted the broadening of dietary recommendations to include greater daily intake of a wider range of vegetables and fruits [2,3] Plant produces these chemicals to protect itself, but recent research demonstrates that many phytochemicals can protect humans against diseases [4]. Phytochemicals are naturally occurring bioactive non-nutrient plant compounds in fruit, vegetables, grains and other plant foods that have been linked to reducing the risk of major degenerative diseases [5]. These phytochemicals have various health benefits such as antioxidant, anti-microbial, anti-inflammatory, cancer preventive, anti-diabetic and antihypertensive effects [6,7]. Flavonoids and other phenolic compounds are potent water soluble antioxidants and free radical scavengers, which prevent oxidative cell damage, have strong anti-cancer activity [8-10]. A number of studies have shown that saponins from different sources lower serum cholesterol levels in a variety of animals including human subjects [11-15]. Fluted pumpkin, tomato and eggplant are amongst the commonly consumed vegetable in the eastern part of Nigeria and thus are important source of nutrient and vitamins for the populace. Nutrient bioavailability broadly refers to the proportion of absorbed nutrient from the diet for use for normal body functions $[16,17]$. Micronutrients and bioactive phytochemicals (e.g. flavonoids, carotenoids) can vary widely in the extent they are absorbed and utilized [18]. This study was undertaken to elucidate the flavonoid, saponins and phenol content of fluted pumpkin leaves, tomatoes and eggplant extracts and their bioavailability in healthy rats. 


\section{Materials and method}

\subsection{Materials}

Fluted pumpkin leaves (Telfairia occidentalis), tomatoes (Solanum lycopersicum) and eggplant (Solanum melongena) were purchased from Ogige market in Nsukka, Enugu State, Nigeria.

\subsection{Method}

\subsubsection{Sample preparation}

Four hundred grammes (400g) of Telfairia occidentalis leaves and Solanum lycopersicum and six hundred grammes $(600 \mathrm{~g})$ of Solanum melongena were washed and blended separately in Warins blender to produce their juice extract using a juice extractor. The quantities of the extracts were $200 \mathrm{ml}, 250 \mathrm{ml}$ and $150 \mathrm{ml}$, respectively. The extracts were bottled, labeled and kept for chemical analysis.

Phytochemical analysis

\subsubsection{Flavonoid determination}

The method of Boham and Kocipai- Abyazan (1994) was adopted for flavonoid analysis. Five grammes (5g) of the sample were extracted repeatedly with $100 \mathrm{ml}$ of $80 \%$ aqueous methanol at room temperature. After extraction, the extracts were whole filtered through Whatman filter paper No $42(125 \mathrm{~mm})$. The filtrates were later transferred into a crucible, evaporated to dryness over a water bath and weighed to a constant weight.

\subsubsection{Saponins determination}

The method of extraction of Obadoni and Ochuko (2001) was adopted. Ten grammes (10g) of the three samples were put into a conical flask and $100 \mathrm{~cm}^{3}$ of $20 \%$ aqueous ethanol was added. The samples each were heated over a hot water bath for $4 \mathrm{~h}$ with continuous stirring at about 55 degrees centigrade. The mixtures were filtered. The residues were reextracted with another $200 \mathrm{ml}$ of $20 \%$ ethanol. The combined extracts were reduced to $40 \mathrm{ml}$ over water bath at about 90 degrees centigrade. The concentrate was transferred into a $250 \mathrm{ml}$ separating funnel containing $20 \mathrm{ml}$ of diethyl ether and shaked vigorously. The methanolic aqueous layer was recovered and the outer layer was discarded. The purification process was repeated. Sixty millilitres $(60 \mathrm{ml})$ of $n$ - butanol was added. The combined $n$ - butanol extracts were washed twice with $10 \mathrm{ml}$ of $5 \%$ aqueous sodium chloride. The remaining solution was heated in a water bath. After evaporation, the samples were dried in the oven to a constant weight, saponins content was calculated as a percentage.

\subsubsection{Phenol determination}

Spectrophotometeric method of Horwitz, William and Latimor (2000) was used. One gramme (1g) of the sample was put into a film container containing twenty millilitres $(20 \mathrm{ml})$ of $80 \%$ ethanol and centrifuged for $15 \mathrm{minutes}$. After this, the upper layer was collected. Five millilitres $(5 \mathrm{ml})$ of the sample was collected in triplicates and $0.5 \mathrm{ml}$ of foliciocaltu reagent was added. After 3minutes, two millilitres $(2 \mathrm{ml})$ of $20 \% \mathrm{NaCO}_{3}$ was added and read at $650 \mathrm{~nm}$ using spectrophotometer 21D.

\subsubsection{Animal study}

Animal and housing: Twenty-four adult male albino rats (70- 120g) were purchased from the Department of Veterinary Pathology, University of Nigeria, Nsukka. The rats were divided into four groups of six each on the basis of body weight and housed in individual stainless steel metabolic cages equipped with screen bottom to separate the faeces and urine. There was an adjustment period of 5 days during which they were fed rat chow and water. After this, the rats were fed rat chow and various extracts for each group of rats as source of fluid ad-libitum for a period of 7 days. Fresh extracts were given to them each morning. The control group received water as fluid. Fluid intakes of the rats were calculated each day.

2.2.6 Laboratory analysis: Carmine red was added to the rat chow on day 5 to mark the beginning of the balance period and on the morning of day 11 to mark the end of the 7-day balance period. The coloured faeces excreted on day 6 were included in the pooled faecal samples and those excreted on day 12 were excluded. Urine was collected from 7:00am of day 5 through the morning of day 12 (7days). Hydrochloric acid $(\mathrm{HCl})(0.1 \mathrm{~N})$ was used to preserve individual urine samples. One millilitre $(1 \mathrm{ml})$ of $0.1 \mathrm{~N}$ of $\mathrm{HCl}$ was added to each pooled urine of each group. Individual faecal collections were dried and weighed before being ground into fine powder.

Blood composition: Blood was collected from the control and the other groups to analyze for flavonoids, saponins, and phenols.

Blood, liver, urine and faeces were analyzed using the following procedures: 


\subsubsection{Flavonoid determination}

The method of Pearson (1976) was used. One gramme (1g) of the sample (faeces) was macerated. Urine and blood were homogenized with $20 \mathrm{ml}$ of ethyl acetate for 5 minutes. The solution was filtered through Whatman filter paper No 42 $(125 \mathrm{~mm})$. Five millilitres $(5 \mathrm{ml})$ of the filtrate were pippetted into a beaker. Five millilitres $(5 \mathrm{ml})$ of dilute ammonia was added to the filtrate and shaked for 5 minutes. The upper layer was collected to read absorbance at 490nm (using Spectro 21D).

\subsubsection{Saponins determination}

The method of Harbone (1973) was adopted for saponins estimation. One gramme (1g) of serum and urine were homogenized, the faeces were macerated with $10 \mathrm{ml}$ petroleum ether. The mixture was filtered and the residue was reextracted with $10 \mathrm{ml}$ petroleum ether. The filtrates were combined and evaporated to dryness. The residue was dissolved with $6 \mathrm{ml}$ of ethanol. Two millilitres $(2 \mathrm{ml})$ of the solution was transferred into a test tube, $2 \mathrm{ml}$ of colour reagent added and allowed to stand for 30 minutes at room temperature. The absorbance was read at 50nm (using Spectro 21D).

\subsubsection{Phenol determination}

This was determined using the method of Harbone (1973). One gramme (1g) of serum and urine were homogenized, the faeces were macerated with $20 \mathrm{ml}$ of $80 \%$ ethanol and filtered. Two millilitres $(2 \mathrm{ml})$ of the filtrate were pipetted into a test tube, and made up to $3 \mathrm{ml}$ with water. A half of a millilitre of foliociocaltu reagent was added and allowed to stand for 3 minutes. Two millilitres $(2 \mathrm{ml})$ of $20 \% \mathrm{NaCO}_{3}$ was added and the absorbance was read at 650nm (using Spectro 21D).

\subsection{Statistical analysis}

All the data generated were analyzed statistically using computer programme Statistical Package for Social Sciences (SPSS) for windows version 16. Means, standard deviation and standard error of the mean were calculated to compare the means.

\section{Main results}

Table 1: Phytochemical composition of fluted pumpkin (Telfairia occidentalis), tomato (Solanum lycopersicum) and eggplant (Solanum melongena) extracts $(\mathrm{mg} / 100 \mathrm{ml})$.

\begin{tabular}{llll}
\hline Phytochemicals & Fluted pumpkin extract & Tomato extract & Eggplant extract \\
\hline Flavonoids & $76.13 \pm 0.02$ & $90.23 \pm 0.04$ & $14.34 \pm 0.02$ \\
Saponins & $60.53 \pm 0.88$ & $52.05 \pm 0.07$ & $73.29 \pm 0.46$ \\
Phenols & $68.09 \pm 0.15$ & $89.13 \pm 0.01$ & $158.14 \pm 0.05$ \\
\hline Mean \pm standard error of mean for three determinations &
\end{tabular}

Table 1 presents the phytochemical composition of fluted pumpkin, tomato and eggplant extract (mg/100ml). The flavonoid content of the three extracts varied from $14.34 \pm 0.02$ to $90.23 \pm 0.04 \mathrm{mg} / 100 \mathrm{ml}$. Eggplant extract had the highest saponins content $(73.29 \pm 0.46 \mathrm{mg} / 100 \mathrm{ml})$ followed by fluted pumpkin $(60.53 \pm 0.88)$ and tomato $(52.05 \pm 0.07$ $\mathrm{mg} / 100 \mathrm{ml})$ extracts. Phenol content of the extracts varied with eggplant extract having the highest value $(158.14 \pm 0.05$ $\mathrm{mg} / 100 \mathrm{ml})$ and fluted pumpkin extract having the lowest value $(68.09 \pm 0.15 \mathrm{mg} / 100 \mathrm{ml})$.

Table 2: Flavonoid retention of rats fed experimental fluid and water (mg)

\begin{tabular}{lllll}
\multicolumn{4}{c}{ Table 2: Flavonoid retention of rats fed experimental fluid and water (mg) } \\
\hline Phytochemical & $\begin{array}{l}\text { Fluted pumpkin } \\
\text { extract }\end{array}$ & Tomato extract & Eggplant extract & Water (control) \\
\hline Fluid intake $(\mathrm{ml})$ & $27.76 \pm 5.96$ & $26.69 \pm 11.41$ & $24.24 \pm 7.79$ & $15.46 \pm 3.22$ \\
Flavonoid intake & $16.57 \pm 0.00$ & $24.08 \pm 0.00$ & $3.48 \pm 0.00$ & - \\
Faecal flavonoid & $1.88 \pm 0.00$ & $1.47 \pm 0.00$ & $1.70 \pm 0.01$ & $1.33 \pm 0.00$ \\
Absorbed flavonoid & $14.69 \pm 0.00$ & $22.61 \pm 0.00$ & $1.78 \pm 0.01$ & $-1.33 \pm 0.00$ \\
Urinary flavonoid & $0.44 \pm 0.01$ & $0.30 \pm 0.00$ & $0.50 \pm 0.01$ & $0.24 \pm 0.00$ \\
Retained flavonoid & $14.25 \pm 0.01$ & $22.31 \pm 0.00$ & $1.28 \pm 0.00$ & $-1.57 \pm 0.00$ \\
Serum flavonoid & $0.82 \pm 0.03$ & $0.43 \pm 0.04$ & $0.66 \pm 0.03$ & $0.26 \pm 0.03$ \\
Tissue store & $13.43 \pm 0.02$ & $21.88 \pm 0.04$ & $0.62 \pm 0.03$ & $-1.83 \pm 0.03$ \\
\hline \multicolumn{2}{r}{ Mean \pm standard error of mean of six rats } & & & \\
\hline
\end{tabular}

Table 2 presents flavonoid retention for rats fed experimental fluids and water. Fluid intake differed from 15.46 \pm 3.22 $\mathrm{ml}$ to $27.76 \pm 5.96 \mathrm{ml}$ in the four groups of rats. Flavonoid intake varied from $3.48 \pm 0.00$ (rats fed eggplant extract) to 
$24.08 \pm 0.00$ (rats fed tomato extract). The faecal flavonoid excretion for the group of rats fed tomato $(1.47 \pm 0.00)$ and fluted pumpkin $(1.88 \pm 0.00)$ extracts were low relative to intake. The faecal flavonoid excretion ranged from 1.33 to 1.88 in the four groups of rats. Absorbed flavonoid varied from -1.33 (control) to 22.61 (rats fed tomato extract). The group of rats fed eggplant extract had the highest urinary flavonoid $(0.50 \pm 0.01)$ with the control having the least $(0.24 \pm 0.00)$. Flavonoid was highly retained in the group of rats fed the tomato extract $(22.31 \pm 0.00)$ with the control having a negative retention $(-1.57 \pm 0.00)$. The serum flavonoid in the four groups of rats varied from $0.26 \pm 0.03$ (control) to $0.82 \pm 0.03$ (rats fed fluted pumpkin extract). Rats fed tomato extract had the highest tissue store of flavonoid $(21.88 \pm 0.04)$ and the control had the least and a negative tissue store of flavonoids $(-1.83 \pm 0.03)$.

Table 3: Saponins retention for rats fed experimental fluid and water (mg)

\begin{tabular}{lllll}
\hline Phytochemical & Fluted pumpkin extract & Tomato extract & Eggplant extract & Water (control) \\
\hline Saponins intake $(\mathrm{mg})$ & $13.17 \pm 0.02$ & $13.89 \pm 0.00$ & $17.77 \pm 0.01$ & - \\
Faecal saponins & $0.20 \pm 0.00$ & $0.19 \pm 0.00$ & $0.21 \pm 0.00$ & $0.16 \pm 0.00$ \\
Absorbed saponins & $12.97 \pm 0.02$ & $13.70 \pm 0.00$ & $17.56 \pm 0.01$ & $-0.16 \pm 0.00$ \\
Urinary saponins & $0.38 \pm 0.01$ & $0.51 \pm 0.01$ & $0.44 \pm 0.01$ & $0.27 \pm 0.00$ \\
Retained saponins & $12.59 \pm 0.01$ & $13.19 \pm 0.01$ & $17.12 \pm 0.00$ & $-0.43 \pm 0.00$ \\
Serum saponins & $0.26 \pm 0.05$ & $0.22 \pm 0.04$ & $0.25 \pm 0.05$ & $0.19 \pm 0.04$ \\
Tissue store & $12.33 \pm 0.04$ & $12.97 \pm 0.03$ & $16.87 \pm 0.05$ & $-0.62 \pm 0.04$ \\
\hline
\end{tabular}

Table 3 presents the saponins retention of the rats fed the experimental fluid and water. The saponins intake varied in the group of rats fed the experimental extracts with the group of rats fed the eggplant extracts having the highest intake $(17.77 \pm 0.01)$ and the group of rats fed fluted pumpkin extract having the lowest intake $(13.17 \pm 0.02)$. Faecal saponins in the four groups of rats ranged from $0.16 \pm 0.00$ (control) to $0.21 \pm 0.00$ (rats fed eggplant extract) with the groups of rats fed tomato and fluted pumpkin extracts having $0.19 \pm 0.00$ and $0.20 \pm 0.00$ respectively. Absorbed saponins in the four groups of rats varied from $-0.16 \pm 0.00$ (control) to $17.56 \pm 0.01$ (group of rats fed eggplant extract). Rats fed tomato extract had the highest urinary saponins $(0.51 \pm 0.01)$. Saponins was highly retained in the rats fed the eggplant extract $(17.12 \pm 0.00)$ followed by the rats fed rats fed the tomato, fluted pumpkin extract and the control $(13.19 \pm 0.01$, $12.59 \pm 0.01$ and $-0.43 \pm 0.00$ respectively). Serum saponins varied from $0.19 \pm 0.04$ (control) to $0.26 \pm 0.05$ (rats fed fluted pumpkin extract). The control had a negative tissue store of saponins $(-0.62 \pm 0.04)$ and eggplant extract had the highest tissue store of saponins $(16.87 \pm 0.05)$.

Table 4: Phenol retention for rats fed experimental fluid and water (mg)

\begin{tabular}{lllll}
\hline \multicolumn{4}{c}{ Table 4: Phenol retention for rats fed experimental fluid and water (mg) } \\
\hline Phytochemical & $\begin{array}{l}\text { Fluted pumpkin } \\
\text { extract }\end{array}$ & Tomato extract & Eggplant extract & Water (control) \\
& $14.82 \pm 0.01$ & $23.79 \pm 0.01$ & $38.33 \pm 0.02$ & - \\
Phenol intake & $0.31 \pm 0.01$ & $0.09 \pm 0.01$ & $0.22 \pm 0.01$ & $0.21 \pm 0.00$ \\
Faecal phenol & $14.51 \pm 0.00$ & $23.70 \pm 0.00$ & $38.11 \pm 0.01$ & $-0.21 \pm 0.00$ \\
Absorbed phenol & $0.65 \pm 0.00$ & $0.36 \pm 0.00$ & $0.73 \pm 0.00$ & $0.29 \pm 0.00$ \\
Urinary phenol & $13.86 \pm 0.00$ & $23.34 \pm 0.00$ & $37.38 \pm 0.01$ & $-0.50 \pm 0.00$ \\
Retained phenol & $0.49 \pm 0.06$ & $0.38 \pm 0.07$ & $0.44 \pm 0.07$ & $0.26 \pm 0.06$ \\
Serum phenol & $13.37 \pm 0.06$ & $22.96 \pm 0.07$ & $36.94 \pm 0.06$ & $-0.76 \pm 0.06$ \\
Tissue store & & & \\
\hline
\end{tabular}

Table 4 presents phenol retention for the rats fed the experimental fluid and water. Rats fed eggplant extract had the highest phenol intake (38.33 \pm 0.02$)$ followed by rats fed tomato and fluted pumpkin extract $(23.79 \pm 0.01$ and $14.82 \pm 0.01$ respectively). Faecal phenol in the four groups of rats ranged from $0.09 \pm 0.01$ (rats fed tomato extract) to $0.31 \pm 0.01$ (rats fed fluted pumpkin extract). The control had a negative value for absorbed phenol $(-0.21 \pm 0.00)$ while rats fed eggplant extract had the highest absorbed phenol $(38.11 \pm 0.01)$. Urinary phenol was lowest in the control group $(0.29 \pm 0.00)$ and the other values were $0.36 \pm 0.00,0.65 \pm 0.00$ and $0.73 \pm 0.00$ for the groups of rats fed tomato, fluted pumpkin and eggplant extracts respectively. Rats fed eggplant extract highly retained phenol (37.38 \pm 0.01$)$ with the least and a negative retention observed in the control $(-0.50 \pm 0.00)$. Serum phenol ranged from $0.26 \pm 0.06$ (control) to $0.49 \pm 0.06$ (rats fed fluted pumpkin extract). Rats fed the eggplant extract had the highest tissue store $(36.94 \pm 0.06)$ of phenol followed by rats fed tomato (22.96 \pm 0.07$)$, fluted pumpkin $(13.37 \pm 0.06)$ extracts and the control which had a negative tissue store $(-0.76 \pm 0.06)$. 
Table 5: Absorption of phytochemicals in rats fed experimental fluid and water (control) (\%)

\begin{tabular}{lllll}
\hline Phytochemicals $(\mathrm{mg} / 100 \mathrm{~g})$ & Fluted pumpkin extract & Tomato extract & Eggplant extract & Water (control) \\
\hline Flavonoid intake & $16.57 \pm 0.00$ & $24.08 \pm 0.00$ & $3.48 \pm 0.00$ & - \\
Faecal flavonoid & $1.88 \pm 0.00$ & $1.47 \pm 0.00$ & $1.70 \pm 0.01$ & $1.33 \pm 0.00$ \\
Absorbed flavonoid & $14.69 \pm 0.00$ & $22.61 \pm 0.00$ & $1.78 \pm 0.01$ & $-1.33 \pm 0.00$ \\
Absorbed (\%) & 88.65 & 93.90 & 51.15 & - \\
Saponins intake & $13.17 \pm 0.02$ & $13.89 \pm 0.00$ & $17.77 \pm 0.01$ & - \\
Faecal saponins & $0.20 \pm 0.00$ & $0.19 \pm 0.00$ & $0.21 \pm 0.00$ & $0.16 \pm 0.00$ \\
Absorbed saponins & $12.97 \pm 0.02$ & $13.70 \pm 0.00$ & $17.56 \pm 0.01$ & $-0.16 \pm 0.00$ \\
Absorbed (\%) & 98.48 & 98.63 & 98.82 & - \\
Phenol intake & $14.82 \pm 0.01$ & $23.79 \pm 0.01$ & $38.33 \pm 0.02$ & - \\
Faecal phenol & $0.31 \pm 0.01$ & $0.09 \pm 0.01$ & $0.22 \pm 0.01$ & $0.21 \pm 0.00$ \\
Absorbed phenol & $14.51 \pm 0.00$ & $23.70 \pm 0.00$ & $38.11 \pm 0.01$ & $-0.21 \pm 0.00$ \\
Absorbed $(\%)$ & 97.91 & 99.62 & 99.43 & - \\
\hline Mean \pm standard error of mean of six rats & & & &
\end{tabular}

Table 5 presents absorption of phytochemicals in rats fed the experimental fluids and water (\%). The percentage of absorbed flavonoid in the group of rats fed the vegetable extracts varied from $51.15 \%$ (group of rats fed eggplant extract) to $93.90 \%$ (group of rats fed tomato extract). Rats fed fluted pumpkin extract had $88.65 \%$ flavonoid absorption. The percentage of absorbed saponins was high in the rats fed the vegetable extracts. The rats fed the fluted pumpkin extract had the lowest value $(98.48 \%)$ relative to those fed tomato $(98.63 \%)$ and eggplant (98.82\%) extracts. Equally, the percentage of absorbed phenol was high with the group of rats who were fed with tomato extract having the highest percentage $(99.62 \%)$ relative to those of the group rats fed the eggplant $(99.43 \%)$ and fluted pumpkin $(97.91 \%)$ extracts.

\section{Discussion}

The flavonoid content of the tomato extract was the highest $(90.23 \pm 0.04 \mathrm{mg} / 100 \mathrm{ml})$ relative to the other two extracts. Flavonoids are potent antioxidant found in most plant species and can account for a significant percentage of the chemical constituents in vegetables, fruits and beverages (such as tea and red wine) [19]. They may account for part of the benefits associated with the consumption of fruits and vegetables [20]. Flavonoids of vegetables have been reported to prevent liver damage which occurs in rats fed cholesterol containing diets [21-25]. Eggplant extract had the highest saponins content $(73.29 \pm 0.46 \mathrm{mg} / 100 \mathrm{ml})$. High saponins was reported in eggplant which in aqueous solution bind cholesterol and have bitterness and hemolytic activity [26]. Phenols, which are associated with diverse functions (including nutrient uptake, protein synthesis, enzyme activity, photosynthesis, structural components and allelopathy) [27], was highest in the eggplant extract $(158.14 \pm 0.05 \mathrm{mg} / 100 \mathrm{ml})$ relative to the other extracts. This might have some nutrition and health implications.

The high serum flavonoid retention was a function of the intake. The higher intake of flavonoids from tomato extracts $(24.08 \pm 0.00)$ and lower faecal and urinary excretions $(1.70 \pm 0.01)$ and $(0.50 \pm 0.01)$ caused the higher absorption and retention for the group of rats fed tomato extract relative to the other groups (Table 2). Before dietary flavonoids are absorbed from the gut, they must be released from plant foods through chewing, action of the digestive juices in the gastrointestinal tract and the microorganisms of the colon [28]. The higher flavonoid retention (22.31 \pm 0.00$)$ as well as tissue store $(21.88 \pm 0.04)$ meant that the flavonoids in tomato extract were available as such the rats ate more and excreted less in both faeces and urine - a commonly observed phenomenon.

The high saponins intake (17.77 \pm 0.01$)$ for rats fed eggplant extract might be due to its level in eggplant extract or other reasons. Ingested saponins are exposed to many potential ligands in the intestine such as bile salts, dietary cholesterol, membrane sterols of the mucosal cells and nutrients or anti-nutrients in foods, all of which may reduce or enhance their effectiveness [29]. The comparable serum saponins and tissue store for rats fed eggplant extract $(0.25 \pm 0.05$, $16.87 \pm 0.05)$ as well as those groups fed tomato extract $(0.22 \pm 0.04,12.97 \pm 0.03)$ and fluted pumpkin extract $(0.26 \pm 0.05$, $12.33 \pm 0.04)$ meant that none of the foods had an edge over the other with regards to serum and tissue saponins. The high tissue saponins store in the group of rats fed eggplant extract $(16.87 \pm 0.05)$ meant high efficacy of tissue to store eggplant saponins.

The higher phenol intake $(38.33 \pm 0.02 \mathrm{mg})$ for rats fed eggplant extract meant that eggplant contain high phenol and/or that plant phenolics occur widely, especially in fruits and vegetables and constitute one of the major groups of compounds acting as primary antioxidants or free radical terminators [30-32]. Antioxidant compounds such as phenols and other phytochemicals play a vital role in removing free radicals and in inhibition of lipid peroxidation [33-35]. The high faecal phenol was high $(0.31 \pm 0.01 \mathrm{mg})$ for rats fed fluted pumpkin extract as well as high urinary excretion for rats fed eggplant extract $(0.73 \pm 0.00)$ meant that phenol was poorly utilized by the rats. The higher serum phenol level 
$(0.49 \pm 0.06)$ for rats fed fluted pumpkin extract showed that it had an edge over tomato extract value $(0.38 \pm 0.07)$. The slight differences in serum phenol levels amongst the three extracts might not suggest that any has an edge over the other in antioxidant property because the same levels of phenolics do not necessarily correspond to the same antioxidant response [36-37]

\section{Conclusion}

The three aqueous vegetable extracts (fluted pumpkin, tomato and eggplant) contained flavonoids, saponins and phenols in appreciable levels. These phytochemicals were highly utilized in rats and stored in both serum and tissues of the rats fed these phytochemicals. Further studies are therefore needed to quantitatively determine phytochemical differentialsflavonoids (flavanols, flavones, isoflavones, flavanones, etc), saponins (triterpenoid saponins and steroid saponins) and phenols- of the vegetable extract.

\section{References}

[1] Carlsen, M. H., Halvorsen, B. L., Holte, K., Bøhn, S. K., Dragland, S., Sampson, L., Willey, C., Senoo, H., Umezono, Y., Sanada, C., Barikmo, I., Berhe, N., Willett, W. C., Phillips, K. M., Jacobs, D. R. Jr, and Blomhoff, R. The total antioxidant content of more than 3100 foods, beverages, spices, herbs and supplements used worldwide. Nutrition Journal, 9, (2010), p.3.

[2] Peters, C. J., Fick, G. W. and Wilkins, J. L. Cultivating better nutrition: can the food pyramid help translate dietary recommendations into agricultural goals? Agronomy Journal, 95, (2003), pp.1424-1430.

[3] Weisburger, J. H. Mechanism of action of antioxidants as exemplified in vegetables, tomatoes and tea. Food and Chemical Toxicology, 37, (1999), pp.943-948.

[4] Kubmarawa, D., M.E. Khan, A.M. Punah and Hassan,. Phytochemical screening and antibacterial activity of extracts from Parkia clappertoniana keay against human pathogenic bacteria. Journal of Medicinal Plant Research, 2, 12, (2008), pp.352-355.

[5] Liu, R. H. Potential synergy of phytochemicals in cancer prevention: mechanism of action. Journal of Nutrition, 134, (2004), pp.34795-34855.

[6] Savithramma, N., Rao, M. L. and Suhrulatha, D. Screening of medicinal plants metabolites. Middle-East Journal of Scientific Research, 8, (2011), pp.579-584.

[7] Rupasinghe, H. P., Jackson, C. J., Poysa, V., Berardo, C. D., Bewley, J. D. and Jenkinson, J. Soyasapogenol A and B distribution in soybean, (Glycine max (L.) Merr.) in relation to seed physiology, genetic variability and growing location. Journal of Agricultural Food Chemistry, 51, 20, (2003), pp.5888-5894.

[8] Salah, N., Miller, N. J., Paganga, G., Tijburg, L., Bolwell, G. P. and Rice-Evans, C. Polyphenolic flavonols as scavengers of aqueous phase radicals as chain breaking antioxidant. Archives of Biochemistry and Biophysics, 322, 2, (1995), pp.339-346.

[9] Del-Rio A, Obdululio B.G., Castillo J,Marin F.G. and Ortuno, A. Uses and properties of citrus flavonoids. Journal of Agricultural and Food Chemistry, 45, 12, (1997), pp.4505-4515.

[10] Okwu, D. E. Phytochemicals and vitamin content of indigenous spices of Southeastern Nigeria. Journal of Sustainable Agriculture Environment, 6, 1, (2004), pp.30-37.

[11] Southon, S., Johnson, I. T., Gee, J. M. and Price, K. R. The effect of Gypsophylla saponins in the diet on mineral status and plasma cholesterol concentration in the rat. British Journal of Nutrition 59, (1988), pp.49-55.

[12] Harwood, H. J. Jr, Chandler, C. E., Pellarin, L. D., Bangerter, F. W., Wilkins, R. W., Long, C. A., Cosgrove, P. G., Malinow, M. R., Marcetta ,C. A., Pettini, J. L., Savoy, Y. E. and Mayne, J. T. Pharmacologic consequences of cholesterol absorption inhibition: alteration in cholesterol metabolism and reduction in plasma cholesterol concentration induced by the synthetic saponin b-tigogenin cellobioside (CP-88818; tiqueside). Journal of Lipid Research, 34, (1993), pp.377-395.

[13] Potter, S. M., Jimenez-Flores, R., Pollack, J., Lone, T. A. and Berber-Jimenez, M. D. Protein saponin interaction and its influence on blood lipids. Journal of Agricultural and Food Chemistry, 41, (1993), pp.1287-1291.

[14] Matsuura, M. Saponins in garlic as modifiers of the risk of cardiovascular disease. Journal of Nutrition, 131, (2001), pp.1000S-1005S.

[15] Al-Habori M \& Raman A. Antidiabetic and hypocholesterolaemic effects of fenugreek (Review). Phytotherapy Research, 12, (1998), pp.233242.

[16] Aggett, P. J. Population reference intakes and micronutrient bioavailability: a European perspective. American Journal of Clinical Nutrition, 91(suppl), (2010), pp.433S-1437S.

[17] Hurrell R and Egli I. Iron bioavailability and dietary reference values. American Journal of Clinical Nutrition, 91, 5, (2010), pp.1461S-1467S. doi: 10.3945/ajen.2010.28674F

[18] European Food Information Council. Nutrient bioavailability- getting the most out of food, (2013).

[19] Hertog, M. G. L., Hollman, P. C. H. and van de Putte, B. Content of potentially anticarcinogenic flavonoids of tea infusions, wines and fruit juices. Journal of Agricultural and Food Chemistry, 41, (1993), pp.1242-1246.

[20] Omoregie, E. S. and Osagie, A. U. Antioxidant properties of methanolic extracts of some Nigerian plants on nutritionally-stressed rats. Nigerian Journal of Basic and Applied Science, 20, 1, (2012), pp.7-20.

[21] Ibarra, M., Perez-Vizcaino, F., Cogolludo, A., Duarte, J., Zaragoza-Arnaez, F. and Lopez-Lopez, J. G. Cardiovascular effects of isorhamnetin and quercetin in isolated rat and porcine vascular smooth muscle and isolated rat atria. Planta Medica, 68, (2002), pp.307-310.

[22] Aoyama, S., Hiraike, T. and Yamamoto, Y. Antioxidant, lipid-lowering and antihypertensive effects of red Welsh onion (Allium fistulosum) in spontaneously hypertensive rats. Food Science and Technology Research, 14, (2008), pp.99-103.

[23] Nakayama, T., Suzuki, S., Kudo, H., Sassa, S., Nomura, M. and Sakamoto, S. Effects of three Chinese herbal medicines on plasma and liver lipids in mice fed a high-fat diet. Journal of Ethnopharmacology, 109, (2007), pp.236-240.

[24] Chen, H.-W., Tsai, C.-W., Yang, J.-J., Liu, C.-T., Kuo, Wi-W. and Lii, C.-K. The combined effects of garlic oil and fish oil on the hepatic antioxidant and drug-metabolizing enzymes of rats. British Journal of Nutrition, 89, (2003), pp.189-200. 
[25] Roldan-Marin, E., Krath, B. N., Poulsen, M., Binderup, M.-L., Nielsen, T. H., Hansen, M.., Barri, T., Langkilde, S., Cano, M. P., SanchezMoreno, C. and Dragsted, L. O. Effects of an onion by-product on bioactivity and safety markers in healthy rats. British Journal of Nutrition, 102, (2009), pp.1574-1582.

[26] Sodipo, O.A., Akiniyi, J.A. and Ogunbamosu, J. A. Studies on certain characteristics of extracts of bark of Pansinystalia macruceras (K schemp) pierre Exbeille. Global Journal of Pure and Applied Science, 6, (2000), pp.83-87.

[27] Wu, H., Haig, T., Prately, J., Lemerie, D. and and An, M. Allelochemicals in wheat (Triticum aestivum 1.): variation of phenolic acids in root tissues. Journal of Agricultural and Food Chemistry, 48, 11, (2000), pp.5321-5325.

[28] Hollman, P. C. H. Absorption, bioavailabilty and metabolism of flavonoids. Pharmaceutical Biology, 42, supplement, (2004), pp.74 - 83.

[29] Francis, G., Kerem, Z., Makker, HPS and Becker K. The biological action of saponins in animal systems: a review. British Journal of Nutrition, 88, (2002), pp.587-605.

[30] Maisuthisakul, P., Suttajit, M. and Pongsawatmanit, R. Assessment of phenolic content and free radical scavenging capacity of some Thai indigenous plants. Food Chemistry, 100, (2007), pp.1409-1418.

[31] Ayoola, G. A., Folawewo, A. D., Adesegun, S. A., Abioro, O. O., Adepoju-Bello, A. .A. and Coker, H. A. B. Phytochemical and antioxidant screening of some plants of apocynaceae from south west, Nigeria. African Journal of Plant Science, 2, 9, (2008), pp.124-128.

[32] Ebrahimzadeh, M.A., Nabavi, S.F. and Nabavi, S.M. Antioxidant activities of methanol extract of Sambucus ebulus L. flower. Pakistan Journal of Biological Sciences, 12, 5, (2009), pp.447-450.

[33] Oke, J. M. and Hamburger, M. O. Screening of some Nigerian medicinal plants for antioxidants activity using 2, 2-diphenyl - picryl hydrazyl radical. African Journal of Biomedical Research, 5, (2002), pp.77 - 79.

[34] Krishnaraju, A.V., Rao, C.V., Rao, T.V.N., Reddy, K. N. and Golakoti Trimurtulu G. In vitro and in vivo antioxidant activity of Aphanamixis polystachya bark. American Journal of Infectious Diseases, 5, 2, (2009), pp.60 - 67.

[35] Aiyegoro, O. A. and Okoh, A. I. Phytochemical screening and polyphenolic antioxidant activity of aqueous crude leaf extract of Helichrysum pedunculatum. International Journal of Molecular Sciences, 10, (2009), pp.4990 - 5001.

[36] Parejo, I., Viladomat, F., Bastida, J., Rosas-Romero, A., Flerlage, N., Burillo, J. and Codina, C. Comparison between the radical scavenging activity and antioxidant activity of six distilled and nondistilled Mediterranean herbs and aromatic plants. Journal of Agricultural and Food Chemistry, 50, (2002), pp.6882-6890.

[37] Demiray, S., Pintado, M. E. and Castro, P. M. L. Evaluation of phenolic profiles and antioxidant activity of Turkish medicinal plants: Tilia argentea, Crataegifolium leaves and Polygonum bistorta roots. World Academy of Science, Engineering and Technology, 54, (2009), pp.312 317. 